\title{
Plankton population and physico-chemical properties of a lake of Jahangirnagar University campus, Bangladesh at various lunar rhythms
}

\author{
Most Fahima Ahmed Anny* and Ismot Ara ${ }^{1}$ \\ Department of Botany, Jahangirnagar University, Savar, Dhaka-1342, Bangladesh
}

\begin{abstract}
Planktonic biomass and physico-chemical properties of water from a lake at Jahangirnagar University, Bangladesh were studied during new moon, first quarter, full moon and last quarter phases from $16^{\text {th }}$ June to $15^{\text {th }}$ July 2015. Twenty four species of phytoplankton belonging to Chlorophyceae, Bacillariophyceae and Euglenophyceae were recorded. Maximum abundance (162-301 unit/1) of Chlorophyceae was recorded in first quarter phase followed by full moon phase (112-224 unit/l), new moon phase (85-222unit/l) and last quarter phase (60-125 unit/l), respectively. Chlorella vulgaris and Biddulphia aurita were the most abundant phytoplankton throughout the lunar period. Among the zooplankton, 5 species of Protozoa, 2 species of Rotifer, 3 species of Cladocera and 1 species of Ostracoda were recorded. Highest zooplankton was recorded in full moon phase (54-105 unit/l) and Daphnia cephalata was the most abundant species throughout the lunar cycle. Physico-chemical parameters indicate that the water temperature, colour, odour and $\mathrm{pH}$ were almost similar throughout the lunar cycle, whereas maximum dissolved oxygen $(7.16 \mathrm{mg} / \mathrm{l})$ and minimum $(4.43 \mathrm{mg} / \mathrm{l})$ were found during the last quarter and the full moon phase, respectively. The highest content of free carbon dioxide (4.36 $\mathrm{mg} / \mathrm{l})$ and chloride $(22.8 \mathrm{mg} / \mathrm{l})$ were recorded during first quarter and full moon phase accordingly.
\end{abstract}

Key words: Lunar rhythm, planktonic biomass, Jahangirnagar University lake.

\section{INTRODUCTION}

The movement of moon on its orbit around the earth produces tidal rhythms that flows twice a day and rhythmic variation of the height of the tides, which are of the considerable importance on plants and animals. Phytoplankton and zooplankton are the important biological indicators of the water quality of a lentic water body and serve as food for aquatic animals and also play an important role in maintaining the biological balance (Perumal et al., 2009). Phytoplankton species diversity responds rapidly to changes in the aquatic environment particularly in relation to nutrients. Many factors reducing phytoplankton diversity may have direct detrimental effects on the amount and predictability of aquatic primary production (Rajkumar et al., 2009). Darkness in the earth's natural photoperiod, and has played a vital role in biological history of all living organisms, be they plants or animals (Moharana \& Patra, 2014).

Lunar rhythm is a phenomenon associated with the life processes of the plankton showing a specific response to light in term of phototaxis. Those which are positive to phototaxis report their maximum rhythmic activities during day light and others being negative in phototaxis are more active in dark (Dhua \& Patra, 2006). It has been recognized that

\footnotetext{
${ }^{1}$ Department of Zoology, Jahangirnagar University, Savar, Dhaka-1342, Bangladesh

*Corresponding author. E-mail: mfa.anny81@gmail.com
} 
zooplankton biomass and abundance assessments produce a higher variability. The zooplankton abundance can vary in relation to illumination by the moon in subtropical waters (Hernández-León et al., 2001). Many researches (Chowdhury \& Mamun, 2005; Chowdhury \& Zaman, 1999; Chowdhury et al., 1998; Chowdhury \& Zaman, 2000; Fakruzzaman et al., 2001; Islam \& Chowdhury, 2013; Islam \& Shaha, 1975) were conducted on the plankton population and diversity in relation to physico-chemical conditions of different water bodies in Bangladesh. But the effects of lunar cycle on the ethological pattern of plankton communities in any lake of Bangladesh have not been studied. Therefore, the present research work was undertaken to investigate the physicchemical properties and planktonic biomass of a lake on the basis of lunar rhythm at Jahangirnagar University in Bangladesh.

\section{MATERIALS AND METHODS}

Plankton (phyto and zooplankton) samplings were made from a lake of Jahangirnagar University (Latitudes of $23^{\circ} 04^{\prime} 00^{\prime \prime} \mathrm{N}$ to $23^{\circ} 04^{\prime} 15^{\prime \prime} \mathrm{N}$ and longitudes of $90^{\circ} 45^{\prime} 10^{\prime \prime} \mathrm{E}$ to $90^{\circ} 47^{\prime} 50^{\prime \prime} \mathrm{E}$ with an average elevation of approximately 12 meter from the sea level) in Bangladesh during a lunar period i.e., $16^{\text {th }}$ June to $15^{\text {th }} \mathrm{July}, 2015$ at 8.00 p.m. Collections were made from 100 litres water sample by a plastic bucket of 10 litres capacity and transferring into a plankton net made of bolting silk cloth (No.25, mesh size $64 \mu$ ). 100 litre of water sample reduced to $50 \mathrm{ml}$ of concentrated sample by filtration through the plankton net and was preserved in 3\% formaldehyde. During the operation, a subsample of $1 \mathrm{ml}$ from the stock was drawn on to the plankton counting cell (1ml capacity). Plankton per litre of water was calculated using formulae as suggested by Edmonson (1995). Qualitative and quantitative estimations of the plankton were made by a Sedgewick-Rafter counting cell as per Fritsch (1965) and Tilden (1968). All the planktons encountered were represented in absolute number. Water temperature of the surface water was measured by using a degree centigrade thermometer, electric conductivity was measured by using an EC meter (Portable EC meter, Sension 5, HACH Company, USA), $\mathrm{pH}$ and Eh (Redox Potential) were measured by using a $\mathrm{pH}$ meter (Portable $\mathrm{pH}$ meter, Sension 1, HACH Company, USA), dissolved oxygen was determined by using the DO meter (Portable DO meter, Sension 6, HACH Company, USA).

\section{RESULTS AND DISCUSSION}

The phytoplankton abundance of the studied water body has been presented in Table 1 . Fourteen species of Chlorophyceae i.e. Actinastrum hantzschii, Chlamydomonas cylindrica, Chlamydomonas angulosa, Chlorococcum infusionum, Chlorella vulgaris, Diacanthos belenophorus, Dictyosphaerium pulchellum, Eudoina elegans, Kirchneriella irregularis, Pediastrum tetras, Schroederia spiralis, Scenedesmus dimorphus, Tetraedron bifurcatum and Tetraedron minimum; 1 species of Baccilariophyceae i.e. Biddulphia aurita and 9 species of Euglenophyceae such as Euglena chlamydophora, Euglena clavata, Euglena deses, Euglena exilis, Euglena flava, Euglena oxyuris, Euglena sanguine, Trachelomonas globularis and Trachelomonas oblonga were recorded. The maximum abundance of Chlorophyceae (162-301 unit/l) was recorded during the first quarter phase followed by full moon phase (112-224 unit/l), new moon phase (85-222 unit/l) and last quarter phase (60-125 unit/l) respectively. Similar results (highest and 
lowest abundance in different phases) also found in Baccilariophyceae and Euglenophyceae. The results indicate that Chlorella vulgaris and Biddulphia aurita were the most abundant phytoplankton throughout the lunar period. It is pertinent to mention here the findings the of Dhua \& Patra (2006) where they mentioned that the lunar cycle imparts certain stimulatory effects on the rhythmic behaviour of plankton and their life processes by which they actively migrate to the surface and gradually sink as the moon fades.

Table 1. Phytoplankton abundance (units/l) of a lake of Jahangirnagar University campus at various lunar rhythms

\begin{tabular}{|c|c|c|c|c|}
\hline \multirow[t]{2}{*}{ Phytoplankton } & \multicolumn{4}{|c|}{ Lunar Period } \\
\hline & $\begin{array}{c}\text { New moon } \\
\text { phase }(16-23 \\
\text { June, 2015) }\end{array}$ & $\begin{array}{c}\text { First } \\
\text { quarter } \\
\text { phase }(24 \\
\text { June-1 }{ }^{\text {st }} \\
\text { July, 2015) }\end{array}$ & $\begin{array}{l}\text { Full-moon } \\
\text { phase }(2-7 \\
\text { July, 2015) }\end{array}$ & $\begin{array}{c}\text { Last } \\
\text { quarter } \\
\text { phase (8- } \\
\text { 15 July, } \\
2015)\end{array}$ \\
\hline \multicolumn{5}{|l|}{ Chlorophyceae } \\
\hline Actinastrum hantzschii Lagerheim & $4-8$ & $7-11$ & $5-9$ & $0-6$ \\
\hline Chlamydomonas cylindrica Chod. & $2-9$ & $8-17$ & $5-14$ & $4-10$ \\
\hline Chlamydomonas angulosa Nyg. & $2-12$ & $5-14$ & $6-10$ & $0-4$ \\
\hline Chlorococcum infusionum (Schrank) & $2-10$ & $5-13$ & $5-10$ & $0-5$ \\
\hline \multicolumn{5}{|l|}{ Meneghini } \\
\hline Chlorella vulgaris Beyerinck & $33-80$ & $60-91$ & $19-66$ & $14-25$ \\
\hline Diacanthos belenophorus & $3-8$ & $4-11$ & $5-14$ & $1-5$ \\
\hline Dictyosphaerium pulchellum & $4-16$ & $10-18$ & $10-14$ & $6-15$ \\
\hline Eudoina elegans & $2-11$ & $6-10$ & $4-8$ & $2-9$ \\
\hline \multicolumn{5}{|l|}{ Smith) Korsikov } \\
\hline Pediastrum tetras (Ehrenberg) Ralfs & $1-3$ & $4-8$ & $5-7$ & $2-5$ \\
\hline $\begin{array}{l}\text { Schroederia spiralis (Printz) } \\
\text { Korsikov }\end{array}$ & $3-9$ & $5-11$ & $4-5$ & $1-5$ \\
\hline Scenedesmus dimorphus (Turp) Kutz & $20-35$ & $27-60$ & $25-40$ & $13-31$ \\
\hline Tetraedron bifurcatum (Wille) & $4-9$ & $6-12$ & $5-9$ & $0-5$ \\
\hline \multicolumn{5}{|l|}{ Lagerheim } \\
\hline $\begin{array}{l}\text { Tetraedron minimum (A. Br.) } \\
\text { Hangsgirg }\end{array}$ & \multicolumn{4}{|c|}{ Hangsgirg } \\
\hline Total & $85-222$ & $162-301$ & $112-224$ & $60-125$ \\
\hline \multicolumn{5}{|l|}{ Baccilariophyceae } \\
\hline \multicolumn{5}{|l|}{ Euglenophyceae } \\
\hline Euglena chlamydophora Mainx & $7-18$ & $10-20$ & $5-14$ & $5-7$ \\
\hline Euglena clavata Skuja & $19-35$ & $22-39$ & $25-30$ & $9-18$ \\
\hline Euglena deses Ehrenberg & $15-26$ & $21-42$ & $22-27$ & $4-16$ \\
\hline Euglena exilis Gojdics & $11-14$ & $8-25$ & $17-21$ & $3-11$ \\
\hline Euglena flava Dangeard & $8-18$ & $9-20$ & $5-15$ & $4-6$ \\
\hline Euglena oxyuris Schmarda & $4-16$ & $10-18$ & $10-14$ & $6-16$ \\
\hline Euglena sanguinea Ehrenberg & $20-33$ & $24-41$ & $25-28$ & $10-17$ \\
\hline $\begin{array}{l}\text { Trachelomonas globularis } \\
\text { (Awerinzew) Lemmermann }\end{array}$ & $2-7$ & $10-15$ & $5-13$ & $0-4$ \\
\hline Trachelomonas oblonga & $2-10$ & $11-17$ & $5-13$ & $0-6$ \\
\hline Total & $88-177$ & $125-237$ & $119-175$ & $45-97$ \\
\hline
\end{tabular}


Zooplankton groups consisted of 5 species of Protozoa i.e. Entamoeba histilytica, Entamoeba coli, Paramecium caudatum, Paramecium buarsaria and Pleuronema chrysalis, 2 species of Rotifer i. e. Brachionus angularis and Brachionus forficula, 3 species of Cladocera i. e. Daphnia carinata, Daphnia cephalata and Moina micrura and 1 species of Ostracoda such as Eucypris virens. Cladocera was the dominant organisms among the zooplankton (Table 2). The number of zooplanktons increased during full moon phase reaching the population maxima (54-105). The result revealed that the Daphnia cephalata was the most abundant zooplankton throughout the lunar cycle.

Table 2. Zooplankton abundance (units/l) of a lake of Jahangirnagar University campus at various lunar rhythms

\begin{tabular}{|c|c|c|c|c|}
\hline \multirow[t]{2}{*}{ Zooplankton } & \multicolumn{4}{|c|}{ Lunar Period } \\
\hline & $\begin{array}{c}\text { New } \\
\text { moon } \\
\text { phase (16- } \\
\text { 23 June, } \\
\text { 2015) }\end{array}$ & $\begin{array}{c}\text { First quarter } \\
\text { phase ( } 24 \\
\text { June- } 1^{\text {st }} \text { July, } \\
2015 \text { ) }\end{array}$ & $\begin{array}{l}\text { Full-moon } \\
\text { phase (2-7 } \\
\text { July, 2015) }\end{array}$ & $\begin{array}{l}\text { Last quarter } \\
\text { phase (8-15 } \\
\text { July, 2015) }\end{array}$ \\
\hline \multicolumn{5}{|l|}{ Protozoa } \\
\hline Entamoeba histolytica Schaudinn & $1-4$ & $3-5$ & $2-8$ & $0-4$ \\
\hline Entamoeba coli (Grassi) & $0-3$ & $5-7$ & $3-5$ & $3-5$ \\
\hline Paramecium caudatum Ehrenberg & $6-11$ & $3-7$ & $8-14$ & $2-3$ \\
\hline $\begin{array}{l}\text { Paramecium buarsaria } \\
\text { (Ehrenberg) }\end{array}$ & $5-8$ & $5-7$ & $9-13$ & $1-3$ \\
\hline Pleuronema chrysalis (Muller) & $0-5$ & $2-8$ & $3-8$ & $1-5$ \\
\hline Total & $12-31$ & $20-32$ & $35-38$ & $13-14$ \\
\hline \multicolumn{5}{|l|}{ Rotifera } \\
\hline Brachionus angularis Gosse & $5-8$ & $3-8$ & $8-14$ & $5-9$ \\
\hline Brachionus forficula Wierzejski & $3-9$ & $7-13$ & $10-16$ & $7-12$ \\
\hline Total & $8-17$ & $15-16$ & $18-30$ & $16-17$ \\
\hline \multicolumn{5}{|l|}{ Cladocera } \\
\hline Daphnia carinata King & $10-35$ & $5-13$ & $20-42$ & $23-31$ \\
\hline Daphnia cephalata (King) & $12-32$ & $4-11$ & $23-45$ & $17-28$ \\
\hline Moina micrura Kurz & $3-16$ & $6-16$ & $11-18$ & $9-13$ \\
\hline Total & $25-83$ & $15-40$ & $54-105$ & $49-72$ \\
\hline \multicolumn{5}{|l|}{ Ostracoda } \\
\hline Eucypris virens & $0-6$ & $3-7$ & $3-8$ & $0-4$ \\
\hline
\end{tabular}

Physico-chemical parameters i.e. temperature, colour, odour, transparency, $\mathrm{pH}, \mathrm{EC}, \mathrm{Eh}$, dissolved oxygen, free carbon dioxide and chloride during new moon, first quarter, full moon and last quarter phases from $16^{\text {th }}$ June to $15^{\text {th }}$ July 2015 presented in Table 3 . The results indicate that the water temperature, colour, odour and $\mathrm{pH}$ were almost similar throughout the lunar cycle; whereas maximum dissolved oxygen $(7.16 \mathrm{mg} / \mathrm{l})$ and minimum $(4.43 \mathrm{mg} / \mathrm{l})$ were found during the last quarter and the full moon phase, respectively. On the other hand highest amount of free carbon dioxide $(4.36 \mathrm{mg} / \mathrm{l})$ and chloride $(22.8 \mathrm{mg} / \mathrm{l})$ were recorded during first quarter and full moon phase accordingly. 
Table 3. Physico-chemical parameters of a lake of Jahangirnagar University campus at various lunar rhythms

\begin{tabular}{l|c|c|c|c}
\hline Parameters & \multicolumn{4}{|c}{ Lunar Period } \\
\cline { 2 - 5 } & $\begin{array}{l}\text { New moon } \\
\text { phase }(16-23 \\
\text { June, 2015) }\end{array}$ & $\begin{array}{l}\text { First quarter } \\
\text { phase }(24 \\
\text { June- } 1^{\text {st }} \text { July, } \\
2015)\end{array}$ & $\begin{array}{l}\text { Full-moon } \\
\text { phase (2-7 } \\
\text { July, 2015) }\end{array}$ & $\begin{array}{l}\text { Last quarter phase } \\
\text { (8-15 July, 2015) }\end{array}$ \\
\hline Water temperature $\left({ }^{\circ} \mathrm{C}\right)$ & 25.0 & 26.0 & 26.0 & 26.0 \\
Weather & Sunny & Sunny & Sunny & Sunny \\
Colour & Greenish & Greenish & Greenish & Greenish \\
Odour & Stagnant & Stagnant & Stagnant & Stagnant \\
Transparency $(\mathrm{cm})$ & 14.0 & 14.5 & 15.75 & 15.5 \\
pH & 7.5 & 7.4 & 7.3 & 7.2 \\
EC $(\mu \mathrm{S} / \mathrm{cm})$ & 287 & 288 & 287 & 284 \\
Eh $(\mathrm{mv})$ & 32.1 & 29.0 & 31.5 & 28.7 \\
DO $(\mathrm{mg} / \mathrm{l})$ & 6.83 & 6.90 & 4.43 & 7.16 \\
Free CO ${ }_{2}(\mathrm{mg} / \mathrm{l})$ & 1.73 & 4.36 & 2.43 & 2.33 \\
$\mathrm{Chloride}(\mathrm{mg} / \mathrm{l})$ & 21.07 & 22.19 & 22.80 & 21.46 \\
\hline
\end{tabular}

EC = Electrolytic Conductivity, $\mathbf{E h}_{=}$Redox Potential, DO = Dissolved Oxygen

The physico-chemical parameters during a lunar cycle followed the same trend in fresh water ecosystem. Different rhythmicity in fresh water planktons of both lentic and lotic ecosystems and correlated it with the variations in light intensity, temperature, transparency and feeding spectrums were reported previously (Patra et al. (1986), Nayak \& Gochhait (1990), Choudhury et al. (1992), Singh \& Srivastava (1993). The favourable physico-chemical parameters of a lake during monsoon provide a suitable back ground to enhance the planktonic population. It can be concluded from the present study that the lunar cycle imparts a stimulating effect on the plankton life processes by which they actively migrate to the surface and then gradually decrease as the phase of the moon decreases. This is a continual cyclic process from one lunar period to another and their maximum and minimum migration is governed ultimately by lunar rhythm. Further study is required to establish planktonic lunar cycle which is important to maintain aquatic ecosystem.

\section{REFERENCES}

Choudhury, S.K., Singh, R.B., Nayak, M. and Choubey, S. 1992. Diurnal profile of some physicochemical and biological parameters in certain perennial pond and river Ganga at Bhagalpur (Bihar). J. Freshwater Biol., 4(1): 45-51.

Chowdhury, A.H. and Mamun, A.A. 2005. Physico-chemical conditions and plankton population of two fish ponds of Khulna. Univ. J. Zool., Raj. Univ. 25: 74-79.

Chowdhury A.H. and Zaman, M. 1999. Zooplankton of the river Padma near Rajshahi, in relation to its physico-chemical conditions. Univ. J. Zool., Raj. Univ. 18: 117-123.

Chowdhury, A.H., Naz, S. and Zaman, M. 1998. Evaluation of water quality and plankton abundance in a canal receiving sugar mill effluent in Rajshahi. J. Asiat. Soci. Bangladesh Sci. 24(2): 283-291.

Chowdhury, A.H. and Zaman, M. 2000. Limnological conditions of the river Padma, near Rajshahi city, Bangladesh. Bangladesh J. Bot. 29(2): 159-165.

Dhua, T. and Patra, A.K. 2006. Lunar rhythm in the planktonic biomass of the Nicco Park lake, Bhubaneswar. Journal of Environmental Biology, 27(4): 739-744.

Edmonson, W.T. 1995. Freshwater Biology. John Wiley and Sons Inc. New York, USA.

Fakruzzaman, M., Chowdhury, A.H., Naz, S. and Zaman, M. 2001. Zooplankton of some fish ponds in Barind Tract in relation to its physico-chemical variables. Univ. J. Zool., Raj. Univ. 20: $75-80$.

Fritsch, F.E. 1965. The structure and reproduction of the algae. Vol.I and II. Univ. Press. Cambridge, London. 
Hernández-León, S., Almeida, C., Yebra, L., Arístegui, J., Fernández de Puelles, M. L. and GarcíaBraun, J. 2001. Zooplankton abundance in subtropical waters: is there a lunar cycle. Sci. Mar., 65: 59-64.

Islam, A.A. and Chowdhury. A.H. 2013. Limnological Status of Trimohini Beel of Rajshahi, Bangladesh J. Asiat. Soci. Bangladesh Sci .39(2): 172-192.

Islam, A.K.M.N. and Shaha, J. 1975. Limnological Studies of the Ramna Lake at Dhaka. Dhaka Uni. Stud. 23B(2): 31-37.

Moharana, P. and Patra, A.K. 2014. Lunar rhythm in the planktonic biomass of Bay of Bengal at Digha-on-Sea (W. B.), Indian J.L.Sci., 3(2): 81-86.

Nayak, L.D. and Gochhait, B.C. 1990. Response of copepods to a lunar rhythm in the river Budhabalanga at Baripada (Orissa). Proc. $77^{\text {th }}$ Ind. Sc. Cong. Part III. Cochin. India Sec. VII: 22.

Patra, A.K., Nayak, L.D. and Patnaik, E. 1986. Lunar rhythm in the planktonic biomass of the River Mahanadi at Sambalpur. Trop. Ecol., 27: 40- 48.

Perumal, N.V., Rajkumar, M., Perumal, P. and Rajasekar, K.T. 2009. Seasonal variations of plankton diversity in the Kaduviyar estuary, Nagapattinam, southeast coast of India. $J$. Environ. Biol., 30: 1035-1046.

Rajkumar, M., Perumal, P., Prabu, V.A., Perumal, N.V., Rajasekar, K.T. 2009. Phytoplankton diversity in pichavaram mangrove waters from south-east coast of India. J Environ Biol., 30: 489-498.

Singh, K.P. and Srivastava, B.L. 1993. Diel pattern of surfacing activity of an air breathing cat fish, Clarius batrachus (L). J. Freshwater Biol., 5(4): 331-342.

Tilden, J.E. 1968. The algae and their life relations. Hafner publication, New York, USA. 